\title{
Utazási célpontok kiválasztásának szempontjai a hazai borturizmusban
}

\author{
Harsányi Dávida, Hlédik Erika ${ }^{b}$ \\ "Budapesti Gazdasági Egyetem \\ bEötvös Loránd Tudományegyetem
}

\section{A TANULMÁNY CÉLJA}

Tanulmányunkban a borturizmusban résztvevők utazási szokásait, borrégiókkal és pincészetekkel kapcsolatos elvárásait és preferenciáit vizsgáltuk.

\section{ALKALMAZOTT MÓDSZERTAN}

A releváns szakirodalmi vonatkozások összefoglalását követően a Nagy Bor Teszt 2018-as adatai alapján elemeztük a borral kapcsolatos utazási hajlandóságot és preferenciákat. Az online kérdőíves felmérés keretében 8552 fó borturizmussal kapcsolatos válaszait vizsgáltuk, majd az utazási gyakoriság alapján három csoportot elemeztünk részletesen: a rendszeres utazókat, akik legalább évente vesznek részt borral kapcsolatos utazáson, a ritkábban utazókat, akik ennél ritkábban utaznak ilyen céllal, és a nyitottakat, akik még soha nem voltak ilyen úton, de szívesen részt vennének valamikor.

\section{LEGFONTOSABB EREDMÉNYEK}

Válaszadóink magas érdeklődést mutattak a borhoz köthető utazással kapcsolatban. Azt tapasztaltuk, hogy eltérések vannak az utazási gyakoriság alapján létrejött csoportok között a borvidék kiválasztása, és a konkrét borászat kiválasztása terén is. A rendszeres utazók nyitottabbak a kevésbé ismert borvidékek irányába, mint a ritkábban utazók. A borászattal kapcsolatos elvárásaik terén is igényesebbek, a borászat által nyújtott élmény (például hangulat, szolgáltatások, étkezés) erőteljesebben jelenik meg körükben, mint a többi csoportnál. A ritkábban utazók, illetve a nyitottak csoportja az ismert borvidékeket látogatná szívesen, és számukra a döntést eröteljesebben befolyásolja, hogy a környéken milyen egyéb látnivalók és programok érhetőek el.

\section{GYAKORLATI JAVASLATOK}

Kutatásunk rávilágított arra, hogy a látogatók számára a helyszín (hangulat, vendégtér, kiegészítő szolgáltatások stb.), étkezési lehetőségek, borász jelenléte is meghatározó szerepet játszik a pincészet kiválasztásánál, vagyis a borturisták komplex élményt keresnek. A borászatnak tehát érdemes szolgáltatáscsomagot kialakítani. Hasznos lehet más piaci szereplőkkel együttmüködni (például az étkezési és szálláslehetőség tekintetében), és ezt eleve felkínálni az érdeklődőknek. A desztinációknak is figyelembe kell venniük, hogy az utazók nagy része (mintánk háromnegyede) egy hétvégét, 2-3 napot töltene borhoz kapcsolódó utazással, tehát programcsomagot érdemes ajánlani számukra. Miután a borvidék ismertsége és pincészetei mellett ugyanúgy fontosak a látnivalók, programlehetőségek, események, így utóbbiakat javasolt fejleszteni, illetve összehangolni.

Kulcsszavak: borturizmus, borfogyasztási preferenciák, bormarketing, desztináció választás

Köszönetnyilvánítás: A Nagy Bor Teszt kutatás 2018-ban a Winelovers, a Magyar Turisztikai Ügynökség, a Vinoport, a Borászportál, valamint a Borkollégium támogatásával készült.

DOI: 10.15170/MM.2020.54.04.07 


\section{BEVEZETÉS INTRODUCTION}

A turizmus, valamint a borkultúra utóbbi évtizedekben megfigyelhető fejlődése egyaránt pozitívan hatott a borturizmus előtérbe kerülésére. A hazai borturizmus kialakulása az 1990-es évektöl kezdődhetett meg, hiszen ekkor indult el a borok minöségi fejlődése, az egyedi pincék kialakulása, amely lehetővé tette a kínálat diverzifikálódását, tényleges utazási célpontok megjelenését. A borturizmus kezdetben a magasabb státuszúak, a bor iránt kifejezetten érdeklődő réteg „kiváltsága” volt. Ez pedig felkelthette a turisztikai szereplök figyelmét az értékes, vagyis az átlagosnál magasabb jövedelemmel rendelkező, az újdonságokra, illetve közösségi programokra nyitott fogyasztói réteg iránt (Bormarketing Mühely 2013). Napjainkban a borturizmus az átlagfogyasztók számára is egyre inkább vonzóvá vált, tehát véleményvezér hatás megfigyelhető ezen a területen is (GFK 2008).

Egy-egy borvidék jelentőségét a térségben nem csak a helyi gazdaságban betöltött szerepe adja (pl. termelés, értékesítés, munkahelyteremtés), hanem turisztikai szempontból is népszerübbé teheti a térséget, növelve az adott desztináció vonzerejét. hozzájárulva az imázsához (Scherrer et al. 2009). A borturizmus beemelése a térség turisztikai kínálatába bővítheti a lehetséges programok, látnivalók számát az alapvetően más célból érkező turisták számára.

A pincészetek számára is jelentős a borturizmus szerepe, hiszen egyrészt közvetlenül a fogyasztónak értékesíthetik a termékeiket (Getz \& Brown 2006, idézi: Alebaki \& Iakovidou 2011), másrészt a találkozás alkalmával edukálhatják őket (GFK 2008), vagy bemutathatják az új fajtákat, termékeket.

Elsősorban a kisebb borászatok számára nyújt fontos lehetőséget a pincénél történő értékesítés, hiszen náluk a megtermelt mennyiség jelentős része így találhat gazdára, mivel az alacsonyabb alkupozíciójukból adódóan a hagyományos kereskedelmi utakon, egységekben történő értékesítés gyakran nem járható út. Számukra tehát alapvető a turizmus szerepe, a fogyasztók pincéhez csábítása. Ehhez természetesen igyekeznek kiegészítő szolgáltatásokat (étkezési, illetve szálláslehetőséget) is kínálni, amelyek szintén bevételnövelö tényezők lehetnek. Léteznek egyébként olyan vállalkozások is (Pallás 2016), amelyek kifejezetten a borturizmusra fókuszálnak, $\mathrm{s}$ a borok értékesítésének is ez lesz az elsődleges csatornája. Egy adott pince alapkínálata azonban általában nem elegendő ahhoz, hogy önmagában odacsábítsa a vendégeket. Ez alól kivételt jelenthetnek az egyedi, magas minőségü borok. Az ágazat marketingorientációja nem mondható elégségesnek (Harsányi és Totth 2014), amely tovább csökkenti a borászatok esélyeit. Ugyanakkor az összefogás további vonzerőt jelenthet. Az egri Szépasszony völgy pincesorának kedveltsége jó példa erre (Györe 2014).

A nagyobb, neves pincészetek számára nem az értékesítés jelenti a legfőbb vonzerőt, hanem a vevőkapcsolatok kialakítása, a vevői kör elkötelezettségének növelése, borászat imázsának megerösítése.

$\mathrm{Az}$ egyes borrégiókban tevékenykedő vállalkozásoknak érdemes lehet összefogni, és egyéb lehetőségeket, komplex programokat kínálni az odalátogatóknak. A Balatoni Kör például borászatok mellett vendéglátóhelyeket tömörít, és a régiót vonzóvá, élhetővé szeretné tenni (Laposa 2020). A borfesztiválok is segítik a turisták vonzását, illetve gyakorta a fesztiválok kínálatának is szerves részét képezik a boros standok. Az egyes régiók, borvidékek nyilvánvalóan különbözö adottságokkal rendelkeznek (természeti és épített környezet, kulturális hagyományok, pincék elhelyezkedése, megközelítése), amelyhez alkalmazkodni kell. A borutak hozzájárulhatnak az egyes borvidékek, térségek, városok komplex desztinációként való fejlesztésében, a turisztikai kínálat összefogásában, programok szervezésében, ugyanakkor megállapítható, hogy a borvidéki összefogás általában még fejlesztésre szorul.

Az elmúlt két évtizedben több vizsgálat történt a borrégiók, borvidékek borturisztikai vonatkozásaival kapcsolatban. Azonban csupán néhány országos szintü empirikus kutatás készült, amely a teljes hazai borturizmust érintette, vizsgálta. Tanulmányunkban a borturistákra fókuszálunk a 2018-as Nagy Bor Teszt adatbázisát felhasználva, melyben a borturizmushoz, "első sorban borhoz köthető belföldi utazásokhoz" kapcsolódó kérdések is szerepeltek. Az elkövetkezendőkben ezekre, vagyis a bor által motivált utazásokra használjuk a borutazás kifejezést. A borutazások gyakorisága, kedvelt célpontjai a korábbiakban már átfogóan bemutatásra kerültek (Harsányi és Hlédik 2019), ebben a tanulmányban részletesen megvizsgáljuk a desztinációválasztás szempontjait, valamint a borturizmusban résztvevők eltérő preferenciáit az utazási gyakoriság alapján létrejött csoportokban.

A borturisták szegmentálásának fontosságára hívja fel a figyelmet Szolnoki (2018), aki tanulmányában a nemzetiség, a látogatás gyakorisága és a régióban vásárolt bor mennyisége alapján szegmentálta a Rheingau borrégióba látogatókat. 
A kutatásunk során a borturizmus iránt érdeklődők célcsoportját vizsgáltuk meg általánosan és a bortúrákon való részvétel gyakorisága alapján szegmensekre osztva. A vizsgálatban az alábbi célokat fogalmaztuk meg:

- a borutazási szokások, illetve hajlandóság áttekintése;

- a borvidékek, mint utazási célpontok kedveltségének bemutatása;

- a desztinációk (borvidékek, pincészetek) kiválasztási szempontjainak ismertetése, a fogyasztók preferenciái.

\section{SZAKIRODALMI ÁTTEKINTÉS LITERATURE REVIEW}

\section{Turizmus, gasztronómia, gasztroturiz- mus hazánkban \\ Tourism, gastronomy, gastro-tourism in Hungary}

A turizmus a 2000-es, illetve 2010-es években húzóágazatnak számított hazánkban (MTÜ 2017). A 2008-2009-es gazdasági válság csupán ideiglenes visszaesést hozott a turisztikai ágazat számára (MT 2012), amely 2010. után folyamatosan fejlődött tovább (MTÜ 2019). A 2011-ben bevezetett Széchenyi Pihenőkártya (SZÉP kártya) egyik fontos célja és eredménye volt a belföldi turizmus élénkítése (MT 2012). 2010 és 2019 között mind a vendégek, mind a vendégéjszakák száma 50\%-kal emelkedett, a szállásdíj bevételek két és félszeres növekedése mellett (MTÜ 2019). Primer kutatásunk évében, 2018-ban a turizmus közvetlenül 6,8\%-kal, közvetve több mint 10\%-kal járult hozzá a GDP-hez, a hazai munkahelyek közvetlenül 10,0\%-át, közvetve 13,2\%-át a turizmus adta (MTÜ 2020). A belföldi turisták legkedveltebb desztinációja a Balaton, második helyen a Budapest-Közép-Dunavidék, a harmadik helyen - az előzőektől jelentősen lemaradva - a két legismertebb borvidéket is magába foglaló Észak-Magyarország voltak (MTÜ 2018).

Magyarországon a gasztro- és borkultúra hoszszú múltra tekint vissza. Az ország adottságai kiválóak a minőségi élelmiszerek termesztésére, így a szőlőművelésre is, a lehetőségek tehát kiemelkedőek a gasztroturizmus, illetve borturizmus számára (Gonda 2016). A borfogyasztók meghatározó része $(85 \%$-a) szerint a bor már a kulináris élvezetekkel hozható kapcsolatba (HNT, 2016), egyre többen gyüjtik is a minőségi borokat, amelyekre akár befektetésként is tekintenek (Erdős és Ormos 2011). A gasztronómiai kínálat sokszínü (Gonda
2016), a magyar konyhamúvészet értéke a változatosság (MT 2013), ami jellemzi a hazai borágazatot is: a szőlőterület 22 borvidékre tagolódik eltérő természeti adottságokkal, borvidékenként akár 20-30 szőlőfajtával. A fogyasztók kevésbé nyitottak a külföldi receptekre (Popovics és tsai 2020), és a külföldi borokra, hiszen 90 százalékban hazai bort fogyasztanak (Harsányi - Hlédik 2017).

Az utazási célpont megválasztásánál a gasztronómia értékei, közte a bor is utazásra ösztönözhetnek, de ezek önmagukban korlátozottan adnak egyedi vonzeröt. Ezért lényeges a desztináció más elemeivel történő összehangolt fellépés (Sulyok 2014).

A gasztronómiai és a borturizmus szerencsére kiválóan köthető egyéb turisztikai termékekhez (MT 2013, Gonda 2016), a legizgalmasabb együttmüködést valószínüleg a fesztiválturizmussal mutatja (Gonda 2016). A gasztronómiai kínálat lényeges elemei lehetnek a gasztronómiai programok, gasztrofesztiválok (Gonda 2016), valamint a hagyományok ápolására és bemutatására szolgáló vásárok (Tóth és tsai 2017). Megállapítható tehát, hogy a komplex turisztikai élmények nyújtanak igazi vonzerőt, amelynek lényeges eleme a térség gasztronómiai kínálatának, ételeinek, borainak fogyasztása (Bormarketing Mühely 2013). A fogyasztók ugyanakkor 10 évvel ezelött hiányolták a kapcsolódó programokat (GFK 2008).

Fontos szerephez jut hazánkban a 2016-ban létrehozott Magyar Turisztikai Ügynökség, amely a turisztikai fejlesztéspolitika megvalósításáért felel (MTÜ 2017). Miután a bor és gasztronómia is része a turisztikai országmárkának, ezért az MTÜ szorosan együttmüködik a borágazat stratégiájáért felelős HNT-vel (Brazsil 2017), valamint a közösségi bormarketingért felelős AMC-vel is.

A pincészetek szerepére hívja fel a figyelmet a 2019-ben bemutatott márkakoncepció, a logó és a „Magyar bor - Személyesen” szlogen, amely érzékelteti azt a változatosságot, ami a piacot jellemzi, valamint kifejezi a hazai borászok lényeges szerepét (MTÜ 2020). Egyben jelzi azt is, hogy a bort a pincénél érdemes megismerni - vagyis turizmusra ösztönzi az embereket.

\section{Borturizmus \\ Wine Tourism}

A hazai turizmus fejlödésével összhangban a borturizmus is dinamikusan fejlődő terület (Várhelyi 2012b), és a turisztikai kínálatunkban egyre jelentösebb szerepet tölt be (Hofmeister-Tóth \& Totth 2018). A vendégéjszakák száma növekedést 
mutatott a válság időszakait leszámítva, mind több turista nyitott két vagy több vendégéjszaka eltöltésére boros szálláshelyen (Pallás 2016).

A borturizmus fogalmának számos definíciójával találkozhatunk a nemzetközi, illetve hazai szakirodalomban. Hall et al. (2000) olyan utazásként határozzák meg, amely során a turisták elsődleges úticélja szőlöültetvények, borászatok, borfesztiválok és borbemutatók látogatása borkóstolás és / vagy a borvidék megismerése céljából. Várhelyi (2012a, 11) definíciója szerint a borturizmus „a borok kóstolása, fogyasztása, készítésének megismerése által motivált utazás." A források egyeznek abban a tekintetben, hogy átfogó, komplex turisztikai élményről, szolgáltatáscsomagról van szó (Getz \& Brown 2006, idézi: Alebaki \& Iakovidou 2011, Sarkadi és tsai 2000, idézi: Tóthné Igó 2012, Secco 2008, idézi: Pallás 2016), amely számtalan elemből áll: vidéki táj, kulturális örökség, fesztiválok, vendéglátás, gasztronómia, találkozás a borásszal, ismerkedés a borral. A borturizmus tehát nem csupán a borfogyasztásról szól, hanem a fogyasztók intellektuális szükséglete és érdeklődése által is motivált.

A borutak jelentős integráló szerepet tölthetnek be az egyes desztinációk életében. A Falusi és Agroturizmus Országos Szövetsége (Fatosz.eu 2020) szerint jelenleg 30 körül van a bejegyzett borút egyesületek száma.

A 2030-ig szóló hazai turizmus stratégia is kiemeli az egységes turisztikai szemlélet fontosságát. A fejlesztések alapja a desztináció lett, így a korábban egymáshoz nem kapcsolódó, gyakran párhuzamos fejlesztések összehangolása egy kézbe került (MTÜ 2017).

A hazai borturisztikai törekvéseket támasztja alá többek között, hogy hazánkban rendezték a 10. Nemzetközi Borturisztikai Konferenciát, a terület legnagyobb presztízsű nemzetközi eseményét (IWINETC, 2018). A bor területéhez kapcsolódóan a turizmus szerepének növekedését az is jelzi, hogy 2016-tól 2019-ig a borturizmus-marketing mellett a közösségi bormarketing feladatokat is a Magyar Turisztikai Ügynökség (MTÜ) látta el, amely így a bor és turizmus területeit közelíteni tudta egymáshoz.

A 2000-es évektől több borturizmussal foglalkozó publikáció látott napvilágot. Ezek fóként egyegy borrégiót, borvidéket vizsgáltak (Szabó 2003, Wachtler \& Nagy-Kovács 2006, Máté 2007, Pallás 2016, Györe 2014, Angler 2016, 2018, Mikházi és tsai 2018). A megjelent szakkönyvek a borturizmus átfogó kérdéseit tekintették át (Sarkadi és tsai 2000, Tóthné Igó 2012, Várhelyi 2012a).
A legjelentősebb hazai boros témájú kutatások megállapításait érdemes röviden összefoglalni. A GFK (2008) kutatása a borturizmust két részre osztotta: a borkóstolók, pincelátogatások, bortúrák kerültek az egyik, a borfesztiválok, bornapok a másik csoportba. A felmérés azt mutatta, hogy a borturizmus még csak kevesek kiváltsága volt, ugyanakkor a borfesztiválok népszerüsége növekedő tendenciát mutatott, amelyek más programmal összekötve (pl. balatoni nyaralás, egyéb események) még vonzóbbak lehetnek (GFK 2008).

A Bormarketing Műhely (2013) kutatása csupán érintőlegesen foglalkozott a borturizmussal. A borfogyasztás helyszínét tekintve az „utazáskor, helyi borászatnál" kategória 23\%-kal a 3. helyen végzett az otthoni (89\%) és a vendégségben (57\%) történő fogyasztás mögött, a borkóstoló programokat $(20 \%)$ megelőzve. A felmérés azt a konklúziót vonta le, hogy ,a magyar lakosság körében egyre népszerübb kulturált borfogyasztás a turisztikai szolgáltatók számára is jelentős potenciált rejt magában" (Bormarketing Mühely 2013, 55).

A Hegyközségek Nemzeti Tanácsa (HNT) vizsgálata kor, nem, településnagyság, régió szerint reprezentatív mintán alapult (Szolnoki \& Totth 2018). Turizmus szempontjából elsősorban a legszívesebben felkeresni kívánt borvidékeket vizsgálta, amely hasonló sorrendet mutatott, mint a fogyasztás szempontjából kedvelt borvidékek.

A Nagy Bor Teszt 2016 óta évente felméri a hazai borfogyasztási, borválasztási szokásokat (Hlédik \& Harsányi 2019). A 2018-as felmérés egyik fókusztémája a borturizmus volt, vagyis a hazai fogyasztók "elsősorban borhoz köthető belföldi utazásokhoz" való hozzáállása (Harsányi Hlédik 2019).

\section{MÓDSZERTAN METHODOLOGY}

Jelen vizsgálat a Nagy Bor Teszt online kutatás 2018 nyarán történt felmérés adatait elemzi. 4 témakörre fókuszált a kutatás: borfogyasztás, borvásárlás, borturizmus, demográfiai jellemzők.

A kérdőív kitöltői nyereményjátékban vehettek részt a kitöltés ösztönzése érdekében (borutazások, borcsomagok, rendezvény és borkurzus belépők, boros jegyzet, szóróajándékok voltak a díjak között). Az önkényes mintavétel során a válaszadók általános, illetve boros weblapokon, Facebook oldalakon keresztül érhették el a kérdőívet. A kérdőívre 21.788 értékelhető válasz érkezett. Tanulmányunkban azon 8552 személyt vizsgáljuk, akik nem boros weboldalról, hírlevélről jutottak el 
a kérdőívhez. A kutatás tehát nem tekinthető reprezentatívnak, ugyanakkor a nagy minta segítségével fontos információkat kaphatunk a bor iránt érdeklödők szokásairól. Az adatelemzés során az SPSS 23 programcsomagot használtuk.

\section{EREDMÉNYEK RESULTS}

A kérdőív válaszadóinak 61\%-a nő, 39\%-a férfi volt. 22\%-a Budapesten él, 23\%-a megyeszékhelyen, $36 \%$-a egyéb városban és $20 \%$-a más településen. A mintába kerültek átlagéletkora 48 év, a legfiatalabb válaszadó 18 éves, a legidősebb 90 éves volt. A válaszadók 52\%-a középiskolai végzettséggel, 47\%-a felsőfokú végzettséggel rendelkezett, az alapfokú végzettségüek alulreprezentáltak (2\%) voltak a mintában.

A borhoz köthető belföldi utazásokon való részvétel gyakorisága alapján határoztuk meg a borturisták almintáját. Az összes megkérdezett közel kétharmada (62\%) szokott borhoz köthető belföldi utazáson részt venni: 39\%-uk legalább évente egyszer tesz ilyen kirándulást, míg 21,5\% ennél ritkábban. A válaszadók 38\%-a nem vett részt ilyen utazáson, viszont $30 \%$ szívesen menne a későbbiekben ilyen utazásra és csak 9\% volt elutasító (1. táblázat).

\section{1. táblázat: Milyen gyakran szokott elsősorban borhoz köthető belföldi utazást tenni (rendezvény vagy pincészet látogatás)? Table 1. How often do you take part in a primarily wine related domestic trip (visiting an event or winery)?}

\begin{tabular}{l|c|c}
\hline & $\mathbf{N}$ & $\mathbf{\%}$ \\
\hline Havonta vagy gyakrabban & 35 & 0,4 \\
\hline Évente több alkalommal & 1422 & 16,6 \\
\hline Évente egy alkalommal & 1903 & 22,3 \\
\hline 2-3 évente & 849 & 9,9 \\
\hline Ennél ritkábban & 989 & 11,6 \\
\hline Részt vettem már külföldi bortúrán, de itthon még soha & 72 & 0,8 \\
\hline Még soha nem vettem részt bortúrán, de szívesen mennék & 2524 & 29,5 \\
\hline Nem voltam még bortúrán, és nem is mennék & 758 & 8,9 \\
\hline Összesen & $\mathbf{8 5 5 2}$ & $\mathbf{1 0 0 , 0}$ \\
\hline
\end{tabular}

Forrás: saját szerkesztés, $N=8552$

Nem túlságosan meglepő módon azok utaznak gyakrabban borutakra, akik (jobban) érdeklődnek a borok iránt: akik borbarátoknak vallják magukat, azoknak $69 \%$-a, a borismeröknek és a borszakembereknek pedig 77\%-a vesz részt évente legalább egy alkalommal bortúrán - szemben a teljes minta átlagos 39\%-ával. Hasonlóan, akik borokat gyüjtenek, azok is nagyobb arányban vesznek részt legalább évente ilyen jellegü utazáson (56\%).

A bortúrán legalább évente résztvevők között a többi csoporthoz képest szignifikánsan magasabb a férfiak (46\%), illetve a felsőfokú iskolai végzettséggel rendelkezők (44\%) aránya. Lakóhely típusa és életkor alapján nem találtunk szignifikáns eltérést a csoportok között.
Azért, hogy megismerjük a borturizmusban résztvevők preferenciáit, a bortúrán való részvétel gyakorisága alapján három csoportra osztottuk a borturizmus iránt érdeklődők körét: akik legalább évente egy alkalommal részt vesznek borhoz köthető belföldi utazáson (Rendszeres utazók, 39\%), akik ennél ritkábban járnak ilyen eseményre (Ritkábban utazók, 21,5\%) és akik még nem vettek részt, de nyitottak (Nyitottak, 30\%). Azokat kiszürtük, akik úgy nyilatkoztak, hogy nem vettek még részt ilyen eseményen, és nem is szeretnének a későbbiekben sem (9\%). Feltételezhető ugyanis, hogy a három csoport borturizmussal kapcsolatos szokásai, preferenciái eltérőek lehetnek. 
A három szegmens borturizmussal kapcsolatos preferenciáit, elvárásait az ilyen utazásra szánt időtartam, a borvidékek vonzereje, a célállomás kiválasztásának szempontjai szerint térképeztük fel.

A borhoz köthető belföldi utazás időtartama meghatározó a megfelelő kínálati stratégia kialakításához. A 2. táblázat azt mutatja, hogy az egyes szegmensek milyen arányban preferálják a különböző hosszúságú bortúrákat, kiegészítve a $\chi^{2}$ statisztika értékével. Mindhárom szegmens esetében a 2-3 napos időtartam preferált leginkább. A szegmensek közötti szignifikáns eltérés abban mutatkozik meg, hogy a ritkábban utazók között minden ötödik csak egy napot szánna egy ilyen programra.

2. táblázat: Hány napot szán(na) átlagosan egy elsősorban borhoz köthető belföldi utazásra? (\%) Table 2. How many days would you spend on a primarily wine related domestic trip? (\%)

\begin{tabular}{|l|c|c|c|c|c|}
\hline & $\begin{array}{c}\text { Rendszeres } \\
\text { utazók }\end{array}$ & $\begin{array}{c}\text { Ritkábban } \\
\text { utazók }\end{array}$ & Nyitottak & Összesen & \\
\hline & $\mathrm{n}=3360$ & $\mathrm{n}=1838$ & $\mathrm{n}=2596$ & $\mathrm{n}=7794$ & $\chi 2 \mathrm{Sig}$ \\
\hline $\begin{array}{l}\text { Legfeljebb egy napot, } \\
\text { ott alvás nélkül }\end{array}$ & $12 \%$ & $21 \%$ & $13 \%$ & $15 \%$ & \\
\cline { 1 - 4 } $\begin{array}{l}\text { Egy hétvégét, 2-3 } \\
\text { napot }\end{array}$ & $78 \%$ & $72 \%$ & $78 \%$ & $76 \%$ & \multirow{2}{*}{$851^{* * *}$} \\
\cline { 1 - 4 } $4-5$ napot & $8 \%$ & $6 \%$ & $8 \%$ & $8 \%$ & \\
\cline { 1 - 4 } Ennél hosszabb időt & $1 \%$ & $1 \%$ & $1 \%$ & $1 \%$ & \\
\hline
\end{tabular}

Megjegyzés: $\chi 2: * * * \mathrm{p}<0,001,{ }^{* *} \mathrm{p}<0,05$

Forrás: saját szerkesztés

Megvizsgáltuk azokat a szempontokat, amelyek befolyásolják a borvidék választást egy borutazáskor. A borvidék ismertsége (44\%), a környékbeli látnivalók (43\%), a borvidék pincészetei (42\%) és a környékbeli események (41\%) egyaránt fontosak a látogatók számára. Az egyes csoportok preferenciáiban jelentős eltéréseket tapasztaltunk. A rendszeres (legalább évente egyszer) látogatók legnagyobb arányban a borvidék pincészeteit (54\%), a borvidéken tartott eseményeket (49\%) tartották legfontosabbnak, ezt követte csak a borvidék ismertsége (43\%). A másik két szegmens tagjai közül legtöbben a borvidék ismertségét és a környékbeli látnivalókat veszik figyelembe a döntés során. Ez utalhat arra, hogy ezen csoportok számára a borhoz kapcsolódó programok mellé más kiegészítő programok még fontosabbak lehetnek. A borutakkal kapcsolatos tapasztalatokkal nem rendelkező, de nyitott szegmens tagjai emelték ki legnagyobb arányban a jó megközelíthetőség jelentőségét. 
3. táblázat: Milyen szempontok alapján választ utazási célpontként hazai borvidéket? (\%)

Table 3. What aspects do you take into considaration when selecting a domestic wine region as a touristic destination? (\%)

\begin{tabular}{|c|c|c|c|c|c|}
\hline & $\begin{array}{l}\text { Rendszeres } \\
\text { utazók }\end{array}$ & $\begin{array}{c}\text { Ritkábban } \\
\text { utazók }\end{array}$ & Nyitottak & Összesen & $\chi 2$ Sig. \\
\hline & $\mathrm{n}=3360$ & $\mathrm{n}=1838$ & $\mathrm{n}=2596$ & $\mathrm{n}=7794$ & \\
\hline A borvidék ismertsége & $43 \%$ & $45 \%$ & $45 \%$ & $44 \%$ & \\
\hline $\begin{array}{l}\text { Környékbeli látnivalók, } \\
\text { egyéb programlehe- } \\
\text { tőségek (pl. evezés, } \\
\text { kalandpark stb.) }\end{array}$ & $38 \%$ & $45 \%$ & $48 \%$ & $43 \%$ & $58,421 * * *$ \\
\hline A borvidék pincészetei & $54 \%$ & $34 \%$ & $31 \%$ & $42 \%$ & $391,853 * * *$ \\
\hline $\begin{array}{l}\text { A borvidéken rendezett } \\
\text { esemény, borfesztivál, } \\
\text { bornapok }\end{array}$ & $49 \%$ & $38 \%$ & $32 \%$ & $41 \%$ & $190,519 * * *$ \\
\hline $\begin{array}{l}\text { A környékbeli szálláshe- } \\
\text { lyek, éttermek }\end{array}$ & $32 \%$ & $31 \%$ & $30 \%$ & $31 \%$ & \\
\hline Elérhetőség, odajutás & $23 \%$ & $28 \%$ & $31 \%$ & $27 \%$ & $47,002 * * *$ \\
\hline Egyéb, éspedig: & $3 \%$ & $4 \%$ & $2 \%$ & $3 \%$ & \\
\hline
\end{tabular}

Megjegyzés: $\chi 2: * * * \mathrm{p}<0,001,{ }^{* *} \mathrm{p}<0,05$

Forrás: saját szerkesztés, $N=8552$

A konkrét pincészet megválasztása egy-egy desztináción belül a helyi borászok közötti verseny során lehet meghatározó.

A konkrét hely megválasztása szempontjából (ld. 4. táblázat) legtöbben a pincészetet, mint helyszínt jelölték meg (56\%), amelynek a hangulata, a vendégtere, a kiegészítő szolgáltatásai meghatározóak lehetnek a döntés szempontjából. Ezt követi az étkezési lehetőség (49\%), a pincészet borászával való találkozás $(40 \%)$ és a pincészet borai $(38 \%)$. Ez utalhat arra, hogy a látogatók a pincészetben eltöltött élmény az elsődleges és nem csak a bor miatt látogatják meg a pincészetet.
Jelentős különbség mutatkozik a szegmensek között a konkrét pinceválasztásban. A rendszeres látogatók szignifinkánsan nagyobb arányban emelték ki a pincészetet, mint helyszínt, és az étkezési lehetőséget, mint a többi szegmens. A pincészet saját rendezvényei szintén ennek a szegmensnek az elvárásaiban jelent meg erőteljesebben. 
4. táblázat: Milyen szempontok alapján választ hazai pincelátogatás esetén konkrét helyet? (\%) Table 4. What aspects do you take into considaration when selecting a winery to visit? (\%)

\begin{tabular}{|c|c|c|c|c|c|}
\hline & $\begin{array}{c}\text { Rendszeres } \\
\text { utazók }\end{array}$ & $\begin{array}{c}\text { Ritkábban } \\
\text { utazók }\end{array}$ & Nyitottak & Összesen & $\chi^{2}$ \\
\hline & $\mathrm{n}=3360$ & $\mathrm{n}=1838$ & $\mathrm{n}=2596$ & $\mathrm{n}=7794$ & \\
\hline $\begin{array}{l}\text { A pincészet, mint helyszín } \\
\text { (hangulat, vendégtér, kiegé- } \\
\text { szítő szolgáltatások stb.) }\end{array}$ & $64 \%$ & $52 \%$ & $48 \%$ & $56 \%$ & $185,311 * * *$ \\
\hline Étkezési lehetőség & $52 \%$ & $46 \%$ & $46 \%$ & $49 \%$ & $31,671 * * *$ \\
\hline $\begin{array}{l}\text { A pincészet borászával / } \\
\text { tulajdonosával való találko- } \\
\text { zás lehetősége }\end{array}$ & $39 \%$ & $42 \%$ & $40 \%$ & $40 \%$ & \\
\hline A pincészet borai & $38 \%$ & $38 \%$ & $38 \%$ & $38 \%$ & \\
\hline $\begin{array}{l}\text { A település központjától való } \\
\text { távolság, megközelíthetőség }\end{array}$ & $34 \%$ & $31 \%$ & $32 \%$ & $33 \%$ & \\
\hline $\begin{array}{l}\text { Szállás helyben, vagy } \\
\text { sétatávra }\end{array}$ & $27 \%$ & $25 \%$ & $24 \%$ & $26 \%$ & \\
\hline $\begin{array}{l}\text { A pincészet saját rendez- } \\
\text { vényei }\end{array}$ & $25 \%$ & $14 \%$ & $12 \%$ & $18 \%$ & $183,533 * * *$ \\
\hline Egyéb, éspedig: ... & $1 \%$ & $2 \%$ & $1 \%$ & $1 \%$ & \\
\hline
\end{tabular}

Megjegyzés: $\chi 2: * * * \mathrm{p}<0,001,{ }^{* *} \mathrm{p}<0,05$

Forrás: saját szerkesztés, $N=8552$

A borvidék vonzereje a borturizmusban meghatározó szerepet tölt be. A válaszadók három olyan borvidéket jelölhettek meg, ahová szívesen utaznának. Az eredmények elemzése során egyértelmúvé vált, hogy a borturisták az ismert, kedvelt borvidékeket preferálják: a válaszadók legnagyobb arányban a Villányi (46\%), a Tokaji (38\%), az Egri $(37 \%)$ és Badacsonyi (35\%) borvidékeket látogatnák meg borturizmus céljából (5. táblázat). Érdekes megfigyelni, hogy a ritkábban utazók és a nyitottak csoportja körében ez a jelenség még erőteljesebben megfigyelhetö: ezek a szegmensek a leginkább ismert borvidékek (Eger, Tokaj és a Balaton-Felvidék) irányában mutatnak az átlagosnál magasabb arányban érdeklődést. Ugyanakkor a rendszeres látogatók érdeklődése jóval diverzifikáltabb a többi borrégió irányába is. Ez az eredmény is megerősíti a borrégiók ismertségének jelentőségét a borturizmusban. 
5. táblázat: Legnépszerübb borvidékek borhoz köthető utazás helyszíneként

Table 5. Most popular wine regions as wine tour destinations

\begin{tabular}{|c|c|c|c|c|c|}
\hline & $\begin{array}{c}\text { Rendszeres } \\
\text { utazók }\end{array}$ & $\begin{array}{c}\text { Ritkábban } \\
\text { utazók }\end{array}$ & Nyitottak & Összesen & $\chi^{2}$ \\
\hline & $\mathrm{n}=3360$ & $\mathrm{n}=1838$ & $\mathrm{n}=2596$ & $\mathrm{n}=7794$ & \\
\hline Badacsonyi & $37 \%$ & $38 \%$ & $40 \%$ & $39 \%$ & \\
\hline Balaton-felvidéki & $24 \%$ & $27 \%$ & $29 \%$ & $26 \%$ & $15,312 * * *$ \\
\hline Balatonfüred-Csopaki & $15 \%$ & $13 \%$ & $14 \%$ & $14 \%$ & \\
\hline Bükki & $5 \%$ & $5 \%$ & $6 \%$ & $5 \%$ & \\
\hline Csongrádi & $2 \%$ & $1 \%$ & $1 \%$ & $1 \%$ & \\
\hline Dél-Balatoni & $6 \%$ & $7 \%$ & $7 \%$ & $7 \%$ & \\
\hline Egri & $38 \%$ & $40 \%$ & $45 \%$ & $41 \%$ & $29,675 * * *$ \\
\hline Etyek-Budai & $9 \%$ & $7 \%$ & $7 \%$ & $8 \%$ & $7,972 * *$ \\
\hline Hajós-Bajai & $4 \%$ & $3 \%$ & $3 \%$ & $3 \%$ & \\
\hline Kunsági & $2 \%$ & $1 \%$ & $2 \%$ & $2 \%$ & \\
\hline Mátrai & $10 \%$ & $12 \%$ & $11 \%$ & $11 \%$ & \\
\hline Móri & $4 \%$ & $2 \%$ & $2 \%$ & $3 \%$ & $11,841 * *$ \\
\hline Nagy-Somlói & $9 \%$ & $6 \%$ & $6 \%$ & $7 \%$ & $25,883 * * *$ \\
\hline Neszmélyi & $5 \%$ & $4 \%$ & $4 \%$ & $5 \%$ & $9,099 * *$ \\
\hline Pannonhalmi & $14 \%$ & $12 \%$ & $12 \%$ & $13 \%$ & \\
\hline Pécsi & $4 \%$ & $4 \%$ & $5 \%$ & $4 \%$ & \\
\hline Soproni & $11 \%$ & $10 \%$ & $10 \%$ & $10 \%$ & \\
\hline Szekszárdi & $24 \%$ & $19 \%$ & $15 \%$ & $20 \%$ & $80,556 * * *$ \\
\hline Tokaji & $38 \%$ & $43 \%$ & $47 \%$ & $42 \%$ & $39,241 * * *$ \\
\hline Tolnai & $2 \%$ & $2 \%$ & $2 \%$ & $2 \%$ & \\
\hline Villányi & $53 \%$ & $52 \%$ & $48 \%$ & $51 \%$ & $11,504 * *$ \\
\hline Zalai & $3 \%$ & $3 \%$ & $4 \%$ & $3 \%$ & \\
\hline
\end{tabular}

Megjegyzés: $\chi 2: * * * \mathrm{p}<0,001,{ }^{* *} \mathrm{p}<0,05$. A válaszadóknak három borvidéket kellett megjelölniük, preferáltságuk alapján rangsorolni azokat. A táblázat az aggregált eredményeket mutatja - a helyezésektöl függetlenül.

Forrás: saját szerkesztés, $N=8552$ 


\section{KÖVETKEZTETÉSEK, JAVASLA- TOK, A KUTATÁS KORLÁTJAI CONCLUSIONS, IMPLEMENTA- TION, AND LIMITATIONS OF THE RESEARCH}

Elsőként érdemes a borászatok számára megfogalmazni a tanulságokat. Az adatok azt mutatták, hogy a látogatók számára több fontos szempont is szerepet játszik a pincészet kiválasztásánál, vagyis komplex élményt keresnek. A legfontosabb szolgáltatáselem maga a helyszín (hangulat, vendégtér, kiegészítő szolgáltatások stb.), amelyet az étkezési lehetöség, illetve a borászat kulcsemberével való személyes találkozás követ. A borkínálat csupán a 4. helyen van. A pince miliőjére kiemelt figyelmet kell fordítani, különösen a rendszeres utazók esetében. A borászatnak tehát érdemes olyan szolgáltatáscsomagban gondolkodni a látogatói élmény megteremtése során, amelyben fenti elemek szerepelnek.

Hasznos lehet más piaci szereplőkkel együttműködni (például az étkezési és szálláslehetőség tekintetében), és ezt eleve felkínálni az érdeklödőknek. A kutatási eredményünk összhangban van a GFK (2008) kutatásának azon megállapításával, amely például a gasztronómiai, a termál-, illetve wellness programokat emelte ki, de a gyermekes családoknak szóló programcsomagokat is megemlítette, mint lehetőség az együttműködésre. Kutatásunk azt mutatja, hogy a kevésbé rutinos borturista szegmensekben erőteljesebben jelenik meg a környékbeli látnivalók, és egyéb programlehetőségek iránti elvárás.

A pincelátogatásra egy 2-3 napos utazás részelemeként érdemes tekinteni, és ebben a csomagajánlatot kínáló résztvevő lépéselőnybe kerülhet. Az utazás tervezett hosszával kapcsolatos információ alapvetően megerősítette a korábbi GFK (2008) kutatás eredményét, amelyben a bortúrák átlagos időtartama 2 nap volt, bár akkor a válaszolók fele csupán egynapos borúton vett részt.

A borvidékek számára is fontos tanulságokkal szolgált a kutatás. A desztinációknak is figyelembe kell venniük, hogy az utazók nagy része (mintánk háromnegyede) egy hétvégét, 2-3 napot töltene borhoz kapcsolódó utazással, tehát programcsomagot érdemes ajánlani számukra. Miután a borvidék ismertsége és pincészetei mellett ugyanúgy fontosak a látnivalók, programlehetőségek, események, így utóbbiakat javasolt fejleszteni, illetve összehangolni. A Bormarketing Mühely (2013) megállapításával ez szinkronban van, amely szerint a célterület turisztikai vonzereje elismert hozzáadott értéket jelent. A kutatásunk azt mutatja, hogy válaszadóink jellemzően a nagyon ismert borvidékeket (Villány, Tokaj, Eger, Badacsony) vagy az ismert turista desztinációkat (Balaton-Felvidék) részesítenék előnyben borutazáskor. A rendszeres utazók ugyanakkor valamivel nyitottabbnak mutatkoznak a kevésbé ismert borvidékek iránt is, ezért ezen desztinációknak érdemes rájuk, vagyis a bor iránt jobban érdeklődő, magasabb végzettséggel rendelkező, inkább férfi célcsoportra koncentrálni. Az adatok alátámasztották, hogy a kedvelt turistahelyekre borozási céllal is szívesebben utaznak az emberek. Ebből leginkább a Balatoni régió (például Badacsony) pincészetei profitálhatnak, hiszen a belföldi utazások elsődleges célpontja a Balaton (MTÜ 2018, GFK 2008).

A bor(utazás) iránt kevésbé érdeklődők még inkább az ismertebb borvidékeket preferálják, amely arra utalhat, hogy a tájékozatlanabb fogyasztók kevésbé kockáztatnának, szívesebben választják a neves „márkákat”.

A kutatás korlátai közé sorolhatjuk, hogy a Nagy Bor Teszt nem reprezentatív mintavételen alapul, ezért az eredmények nem általánosíthatóak a hazai lakosságra. Ugyanakkor a kérdőív kitöltők a bor iránt valamilyen érdeklődést mutatók köréből került ki, és a nagy mintaelemszám ebben a célcsoportban részben ellensúlyozza ezt a hiányosságot, lehetöséget adva alminták elemzésére, és ezen csoportokban az eltérő jellemzők, preferenciák összehasonlítására.

Jövőbeli kutatási irányként jelölhetjük meg klaszterelemzés elvégzését a komplexebb szegmentálás érdekében, valamint a felmérés újbóli lebonyolítását az eredmények validálása, illetve az esetleges változások követése céljából. Természetesen hasznos lenne a vizsgálatot reprezentatív mintán is elvégezni megfelelő financiális háttér esetén.

\section{ÖSSZEFOGLALÁS SUMMARY}

Hazánk jó adottságokkal rendelkezik a turizmust, illetve a borturizmust illetően, jelentős előnye a változatos kínálat. Az elmúlt időszakban egyértelmű fejlődés tapasztalható, amelyet az utazási statisztikák is alátámasztanak. A bor gyakran nem elegendő vonzerő az utazáshoz, azonban jelentős kiegészítő tényező. Primer vizsgálatunk is alátámasztotta, hogy az utazási célpont kiválasztásánál további szempontok is szerepet játszanak (látnivalók, rendezvények). 
Tanulmányunkban a Nagy Bor Teszt 2018-as adatai alapján elemeztük a borral kapcsolatos utazási hajlandóságot és preferenciákat. Kutatásunk validitását erősíti, hogy eredményeink hasonló trendeket és preferenciákat mutatnak a borturisták körében, mint a korábbi kutatások. Ugyanakkor a nagy minta lehetővé tette a borturisták utazási gyakoriság alapján történő megkülönböztetését, így a borutazók preferenciáinak árnyaltabb megismerését, különösen a rendszeres borutazók szokásainak, a desztináció kiválasztási szempontjainak feltérképezését. Azt tapasztaltuk, hogy eltérések vannak az utazási gyakoriság alapján létrejött csoportok között a borvidék kiválasztása, és a konkrét borászat kiválasztása terén is. A rendszeres (legalább évente) utazók nyitottabbak a kevésbé ismert borvidékek irányába, mint a ritkábban utazók. A borászattal kapcsolatos elvárásaik terén is igényesebbek, a borászat által nyújtott élmény (például hangulat, szolgáltatások, étkezés) erőteljesebben jelenik meg körükben, mint a többi csoportnál. A ritkábban utazók, a nyitottak csoportja az ismert borvidékeket látogatná szívesen, és számukra döntést erőteljesebben befolyásolja, hogy a környéken milyen egyéb látnivalók és programok érhetőek el.

Eredményeink újszerüségét adja az is, hogy a teljes hazai borpiacon vizsgálja a kiemelt borturista célcsoportot, illetve választási kritériumokat.

\section{HIVATKOZÁSOK REFERENCES}

Alebaki, M. and Iakovidou, O. (2011), "Market segmentation in wine tourism: a comparison of approaches", Tourismos: An International Multidisciplinary Journal of Tourism, 6(1), 123140 DOI: $10.1080 / 09571264.2015 .1051218$

Angler K. (2016), „Egyedül nem megy!” Formális és informális együttmüködések sikeres gyakorlatai Szekszárd borturizmusáért, In: Ivancsóné Horváth Zs. - Darabos F. (szerk): Turizmus és Innováció - VIII. Nemzetközi Turizmus Konferencia 2016 Tanulmányok, 51-63

Angler K. (2018), Helyi termékek szerepe a Szekszárdi borvidék gasztronómiájában, Egy borvidék - egy település marketing szempontú vizsgálata, In: Generációk a Turizmusban Tanulmánykötet, Pécs, I. Nemzetközi Turizmusmarketing Konferencia, 51-61

Bormarketing Mühely (2013), Bormarketing munkát támogató piackutatás a magyar borpiacon. Kutatási jelentés. http://www.bor.hu/20130410 friss_orszagos_fogyasztoi_kutatas_a_borrol (Letöltve: 2014.03.03.)

Brazsil D. (2017), A bor és a turisztikai országmárka, Borászati füzetek, 28(3), 5-7

Erdős P. - Ormos M. (2011), Borok, mint alternatív befektetési lehetőségek, Közgazdasági Szemle, 58(2), 158-172.

Fatosz.eu (2020), Magyar Borutak Országos Szövetsége, $\quad \mathrm{http}: / / \mathrm{www} \cdot$ fatosz.eu/?11=static content $\& 12=$ plug_static_content $\& 13=-$ main\&id=206 (Letöltve: 2020.07 .11 .)

GFK (2008), Bor - Feltáró kutatás. Kutatási jelentés

Gonda T. (2016), A turisztikai termékfejlesztés elméleti alapjai, PTE http://lib.igyk.pte.hu/libletoltes/karikiadvanyok/Gonda\%20Tibor_A_ turisztikai_termekfejlesztes_elmeleti_alapjai. pdf (Letöltve: 2020.05.25.)

Györe D. (2014), A közvetlen értékesités szerepe az egri borvidéken. $\mathrm{PhD}$ értekezés, Gödöllö.

Hall, C. M., Cambourne, B., Sharples, L. and Macionis, N. (2000), Wine Tourism Around the World: Development, Management and Markets. Routledge

Harsányi D. - Hlédik E. (2017), „A hazai borfogyasztói szegmensek 2016-ban", in: Bányai E. - Lányi B. - Töröcsik M. (szerk.), Tükröződés, társtudományok, trendek, fogyasztás, EMOK XXIII. Országos Konferencia tanulmánykötet 179-188.

Harsányi D. - Hlédik E. (2019), „Borturizmus fogyasztói szemszögből - a borral kapcsolatos 
utazásokon résztvevők szokásai és preferenciái”, in Csapó J. - Gonda T. - Raffay Z.: Turizmus, Fogyasztás, Generációk, II. Nemzetközi Turizmusmarketing Konferencia, Pécs

Harsányi D. - Totth G. (2014), „A megújulás szükségessége a hazai borászatok marketing tevékenységében", in Hetesi E. - Révész B. (szerk), „Marketing megújulás” Marketing Oktatók Klubja 20. Konferenciája előadásai, 283-295.

Hlédik E. - Harsányi D. (2019), "Towards quality consumption, Segmentation of the Hungarian wine market based on wine consumption and purchasing habits", International Journal of Wine Business Research, 31(4), 602-617. DOI: 10.1108/IJWBR-10-2018-0063

HNT (2016), Hegyközségek Nemzeti Tanácsa: Magyarország szölészetének és borászatának helyzete - Háttértanulmány az ágazati stratégiához.

Hofmeister-Tóth Á. - Totth G. (2018), ,Marketingkommunikáció a borágazatban". in: Veszelszki Á. (2018): Borkommunikáció, Századvég. 108123

IWINETC (2018), International Wine Tourism Conference hivatalos webodala, https://www.iwinetc.com/2018hungary/ (Letöltve: 2019.01.29.)

Laposa B. (2020), balatoni-kor.hu, (Letöltve: 2020.07.15.)

Máté A. (2007), „A, „Pannon Borrégió” Borútjainak összehasonlító értékelése", Modern Geográfia 2(4), 1-15

Mikházi Zs. - Sallay Á. - Máté K. - Csemez A. (2018), A borturizmus múltja, jelene és jövője az Etyek-Budai borvidéken. Turizmus Bulletin. 18(1), 4-16

MT (2012), Új vizeken tovább 2012. Marketingterv, Magyar Turizmus Zrt. Budapest

MT (2013), „Magyar Turizmus Zrt.: A bor és gasztronómia, mint turisztikai termék", Turizmus Bulletin, 15(1), 45-49

MTÜ (2017), Nemzeti Turizmusfejlesztési stratégia 2030, Magyar Turisztikai Ügynökség, Budapest, https://mtu.gov.hu/documents/prod/mtu_strategia 2030.pdf (Letöltve: 2020.05.20.)

MTÜ (2018), A magyar lakosság belföldi és külföldi utazásai 2017-ben, https://mtu.gov.hu/ documents/prod/magyarok_utazasai_2017.pdf (Letöltve: 2020.05.20.)

MTÜ (2019), A turizmus eredményei Magyarországon, Magyar Turisztikai Ügynökség, https://mtu.gov.hu/cikkek/2019-ben-ismet-rekordot-dontott-a-magyar-turizmus-1425 (Letöltve: 2020.05.20.)

MTÜ (2020), A turizmus eredményei Magyarországon, Magyar Turisztikai Ügynökség, https://mtu.gov.hu/cikkek/a-turizmus-ered- menyei-magyarorszagon (Letöltve: 2020.05.20.)

Pallás E. (2016), A borturisztikai lehetőségek vizsgálata kisvállalkozások körében, a Tokaji borvidéken. in: Ivancsóné Horváth Zs. - Darabos F. (szerk): Turizmus és Innováció - VIII. Nemzetközi Turizmus Konferencia 2016 Tanulmányok. 380-393

Popovics P. - Soós M. - Szakály Z. - Kiss V. Á. (2020), „A személyes értékek, az idegen ízek és az újdonságkeresés közötti kapcsolat a hazai étkezési kultúrában", Marketing \& Menedzsment, 2. különszám DOI: 10.15170/ MM.2020.54.KSZ.II.02

Sarkadi E. - Szabó G. - Urbán A. (2000), Borturizmus szervezők kézikönyve. Baranya Megyei Falusi Turizmus Szövetség, Pécs

Scherrer, P., Alonso, A. and Sheridan, L. (2009), "Expanding the destination image: wine tourism in the Canary Islands", International Journal of Tourism Research, 11(5), 451-463 DOI:10.1002/ jtr.713

Sulyok J. (2014), A turisztikai termékfejlesztés helyi sajátosságai vízparti településeken, in: Tózsa I. (szerk.), Turizmus és településmarketing, Budapesti Corvinus Egyetem

Szabó G. (2003), A borturizmus, a borutak kialakításának tapasztalatai a Dél-Dunántúli Régió borvidékein, in: Kovács D. (szerk.), A falusi turizmus hagyományai. Mezőgazda, Budapest. 133-142

Szolnoki, G. (2018), "New approach to segmenting tourists in a German wine region", International Journal of Wine Business Research. 30(2), 153168. DOI: 10.1108/IJWBR-07-2017-0044

Szolnoki G. - Totth G. (2018), A magyar borszektor elemzése piaci és fogyasztói szempontból. Borászati Füzetek. 28(1), Melléklet 1-30

Tóth B. - Nagy Gy. - Hegedűs G. (2017), „A helyi értékek és Hungarikumok turisztikai attrakcióvá való fejlesztési lehetôségei alföldi példákon keresztül", Turisztikai és Vidékfejlesztési Tanulmányok, 2(2), 4-19

Tóthné Igó Zs. (2012), Tematikus utak, borutak. Eszterházy Károly Főiskola, Eger

Várhelyi T. (2012a), Borturizmus. Liceum Kiadó, Eger

Várhelyi T. (2012b), „A borturizmus és jótékony hatásai", Turizmus Online, http://www.turizmusonline.hu/cikk_a_borturizmus_es_jotekony hatasai; (Letöltve: 2019.01.24.)

Wachtler I. - Nagy-Kovács E. (2006), „A borturizmus az Észak-Magyarországi Régióban”, Gazdálkodás. 50(15. különszám), 70-81 
Harsányi Dávid, $\mathrm{PhD}$, tanszékvezető egyetemi docens

Harsanyi.David@uni-bge.hu

Budapesti Gazdasági Egyetem

Hlédik Erika, PhD, egyetemi adjunktus hledik@gti.elte.hu

Eötvös Loránd Tudományegyetem

\section{Aspects of selecting touristic destinations in Hungarian wine tourism}

\section{THE AIMS OF THE PAPER}

The paper examines the traveling habits of Hungarian wine tourists, their expectations and preferences towards wine regions and wineries.

\section{METHODOLOGY}

After reviewing the relevant literature on the topic, we analysed the willingness and preferences of wine tourists upon the data of the Great Wine Test 2018. We used the answers of 8552 respondents of the online questionnaire. Upon travelling frequency, we analysed three groups in detail: frequent travellers, who take part in a wine tour at least once a year, occasional travellers, who travel less frequently, and interested travellers, who has never been on a wine tour but are open to take part someday.

\section{MOST IMPORTANT RESULTS}

Respondents showed high interest towards wine tourism. But differences can be found between the groups regarding the selection of wine regions and wineries. Frequent travellers are more open to less known wine regions than other travellers. They have higher expectations towards a winery, the winery experience (such as the milieu, services, dining) is more important. Occasional and interested travellers would rather visit the well-known wine regions, and their decision is influenced more by the sights and programs of the area.

\section{RECOMMENDATIONS}

The research showed that the location (milieu, guest area, additional services, etc.), dining opportunities, presence of the winemaker determine the selection of a winery, so wine tourists look for a complex experience. Therefore, wineries should develop a service package. It can be beneficial to cooperate with other market actors (e.g. in the case of dining and accommodation) and offer these services to prospective travellers. Destinations should take it into consideration that most travellers (three quarters of our sample) would spend one weekend, 2-3 days on a wine tour, therefore a set of programs should be offered for them. Since the sights and program opportunities as important as the publicity and the wineries of the wine region, these aspects should be developed and synchronised.

Keywords: wine tourism, wine consuming preferences, wine marketing, destination choice

Acknowledgements: The Great Wine Test in 2018 was supported by Winelovers, Hungarian Tourism Agency, Vinoport, Borászportál, and Borkollégium. 